\title{
Assessment of the economic value of irrigation water considering achieve main crops self-sufficiency: Case study Sharkia Governorate, Egypt
}

\author{
Hazem Eldeeb ${ }^{1}$, Martina Zelenakova ${ }^{2 *}$ \\ ${ }^{1}$ Water and Water Structures Eng. Department., Faculty of Engineering, Zagazig University, \\ Zagazig 44519, Egypt, email: heldeeb@zu.edu.eg \\ ${ }^{2}$ Department of Environmental Eng., Faculty of Civil Eng., Technical University of Kosice, \\ Kosice 04200, Slovakia, email: martina.zelenakova @ tuke.sk \\ * Correspondence: martina.zelenakova@tuke.sk; Tel.: +421-905-985-765
}

\begin{abstract}
The water shortage issue may put a spotlight over most of the Middle East region and push many nations to replanning the water resources in various respects. Providing data on water's economic value assists policymakers make informed decisions regarding water distribution. Additionally, addressing the increasing demand for all uses and building the sustainable future of agricultural and water policies. The purpose of this article is to explore and evaluate the economic value of irrigation water in Sharkia Governorate, regarded one of Egypt's largest provinces. It also examines how to maximize the economic value of irrigation water, taking into account the self-sufficiency of main crops. Furthermore, consideration has been given to the political demands for the allocation, management and control of water resources. The simulation software Operational, Planning and Distribution Model (OPDM) was used to simulate through the studied province the accessible water distribution and crop yield. Moreover, it is used to judge the impact of irrigation water utilization and to check gross income. Furthermore, from a technical and economic point of perspective, the distinct suggestions were contrasted. The research evaluates the present crop pattern for wheat and cotton attaining a peak economic value of $1.23 \mathrm{EGP} / \mathrm{m}^{3}$ and $0.98 \mathrm{EGP} / \mathrm{m}^{3}$ of irrigation water for wheat and cotton respectively. Moreover, it reaches $0.41 \mathrm{EGP} / \mathrm{m}^{3}$ for rice which considered one of the highest plants in water consumption. Finally, these findings may highlight some strategic crops future development.
\end{abstract}

Key words: economic value, irrigation water, water resources management, cropping pattern, Sharkia Governorate.

\section{Introduction}

Water is not a product or business asset, this is a resource that should be valued by mankind. Egypt's water resources are becoming insufficient. Surface water resources from the River Nile are generally totally explored, with full development of accessible revealed groundwater sources. Egypt is dealt with increasing water needs via a steadily growing inhabitants, higher 
living standards and agriculture initiatives and regulations [1]. Agriculture is typically a river basin's hugest water-consuming enterprise, so its climatological-risk water-use plan is related to sustainable water resource productivity throughout the region [2].

More than a million individuals a year are presently growing the population in Egypt. Improved agency and management processes of water adequacy, assignment and use are mostly recommended important procedures to creating appropriate use of the water available. For most places, the key constraint is the ability to produce visionary water management strategy, together with the required legislation and administration to promote it.

This will no longer be feasible for Egypt to reach its boundaries of accessible water and Egypt will have to face variable supply circumstances. The ideal use of water is therefore one of the ways in which this issue can be addressed; the financial or economic value of water is one of the most significant variables to be concentrated. Government policies are aimed for reducing the consumption of agricultural water and rationalizing water consumption taking into account social and environmental issues.

Agriculture consumes the largest quantity of water available in Egypt, with its share slightly below $85 \%$ of complete water demand. The agricultural sector in the Egyptian economy contributes approximately $13.22 \%$ to gross national product and propositions approximately $34 \%$ of total jobs. Municipal water demand was estimated at 9.0 billion cubic meters (BCM), with roughly $95 \%$ of the Egyptian population relying on water distribution networks, Ministry of Water Resources and Irrigation $[3,4]$.

The value of water represents the financial, cultural and environmental values of society [5]. Water's economic or financial value depends on both the customer and the use. Since it is scarce and can be used in distinct ways, water can have a strong economic value. Knowledge of the economic value of water encourages policymakers to make knowledgeable water decisions development, distribution and use in facing its increasing scarcity when increasing requirements for all uses are made [6]. To sum up, precise estimates of the economic value of water are needed for the rational distribution of water shortages across places, uses, customers and timeframes [6].

The present study's primary goal is to scrutinize the financial results of irrigation water and improve the environmental and social efficiency of irrigation water at Sharkia Governorate, one of Egypt's largest provinces.

\section{Literature review}

The River Nile is Egypt's primary water source, with an assigned annual flow of 55.5 $\mathrm{BCM} / \mathrm{year}$ under the 1959 Nile water agreement. It is estimated that internal renewable surface water resources are $0.5 \mathrm{BCM} /$ year. This gives up to $56 \mathrm{BCM} /$ year of complete real renewable surface water resources. It is estimated that internal renewable groundwater resources are 1.3 billion $\mathrm{BCM} /$ year.

The overlap between surface water and groundwater is regarded negligible, making the country's complete real renewable water resources 57.3 BCM/year [7]. There are countless earlier water resource management studies in Egypt. A short research was provided on cost recovery in water systems [8]. In addition, the water valuation research was introduced, moreover, a demand management tool was submitted in Egypt [5]. Additionally, there are many water policy integration research in Egypt [7,9]. Water value should represent society's 
financial, environmental and cultural values [5]. While there is infinite supply of water, it is economically free. Obviously, water economic value estimates are crucial if scarce water is to be allocated efficiently and equitably [6].

Water is a tremendous resource. This implies that its economic value tends to be relatively small per unit weight or quantity. Its transport therefore needs a high cost per volume unit and is unless a high marginal value can be attained, it is often not economically viable over lengthy distances. The abstraction, storage and any transportation expenditures tend to be exceptional compared to the small economic value of using an extra water unit. This can generate water values particular to the location [10].

Increasing the development of water based on food consumption and optimizing the allocation of water resources were studied [11]. In addition, an optimization model was developed in terms of plant water productivity and a mathematical model was developed to maximize income per unit of water based on optimum crop pattern [11].

Digital Water Resources Management (WRM) depictions have become increasingly accessible in the form of digital models (DMs) over the past twenty years. It is quicker to use computers and extract information from digital models, providing more reproducible readings than traditional manual methods. A try to quantify the potential for runoff in all India's basins using remote sensing data [12] was used. The SCS technique has been used. Complex map of hydrological soil cover has been acquired by incorporating map of land use and map of soil type. In addition, GIS was used as an instrument to assess the potential of surface water [13]. This article analyzes the water policy planning of the region and suggests highlighting the features of this planning attempt in the governorate of Sharkia. Including irrigation and drainage processes, an extensive water resources map was prepared. Furthermore, consideration was given to the political demands for the allocation, management and control of water resources.

The Operational, Planning and Distribution Model (OPDM) was used throughout the studied province to simulate the accessible distribution of water and crop yield. Furthermore, the gross income has been researched. Such an assessment is important because there are currently very restricted and mainly undocumented knowledge of Egyptian water economic value.

Many suggestions have been explored to show the model's use and to show the current water resource management scenario. Finally, the current water financial values are described and assessed for the primary crops.

\section{Collected data utilized}

On the basis of information supplied by the Ministry of Irrigation and Water Resources (MIWR); Irrigation Sector (IS), Ministry of Agriculture and Land Reclamation (MALR), the possible distinct conditions were created.

The information includes the present crop pattern, water requirements for each crop, complete cost of each crop being cultivated. The costs include preparation of land, seeds, fertilizers, irrigation or agricultural services, pest control, harvesting, transportation of crops and the costs of public expenditure and total income per feddan for each crop. 


\section{Model description}

The Operational, Planning and Distribution Model, OPDM, is one of the most advanced software developed in complicated canal and drainage networks to simulate water distribution and crop yield reaction. Based on the given plant patterns and weather data, the OPDM is used to assess plant water requirements.

The modeled water quantities are transmitted through a primary main canal scheme, groundwater aquifers, downstream streams, and open drains.

\subsection{Theoretical approach}

The OPDM model is used in this paper to calculate theoretically different parameters affect the irrigation water consumption. These parameters include wind speed, leaching factor and salinity as follows [14]:

- Wind speed

$$
U_{2}=4.852 U_{z} / \ln (z-0.08 / 0.015)
$$

Where: $U_{2}$ is the wind speed at $2.0 \mathrm{~m}(\mathrm{~m} / \mathrm{s})$; and $U_{z}$ is the recorded velocity $(\mathrm{m} / \mathrm{s})$ at $z(\mathrm{~m})$ above ground surface.

- The leaching factor

$$
L F=E C_{i w} / E C_{d w}=D_{d w} / D_{i w}
$$

Where: $L F$ is the leaching factor (from 0 to 1.0 ); $E C_{i w}$ is the irrigation water electrical conductivity $(\mathrm{dS} / \mathrm{m}) ; E C_{d w}$ is the drainage water electrical conductivity, or deep percolation, water $(\mathrm{dS} / \mathrm{m}) ; D_{d w}$ is the depth of drainage water $(\mathrm{m})$; and $D_{i w}$ is the depth of infiltrated water from the soil surface $(\mathrm{m})$.

- The deficit yield reduction

$$
Y_{\text {rel }}=100 \prod_{i=1}^{n}\left(E T_{a} / E T_{p}\right)_{i}^{\lambda_{i}}
$$

Where: $Y_{r e l}$ is the relative yield $(\%) ; E T_{a}$ is actual transpiration $(\mathrm{mm} / \mathrm{day}) ; E T_{p}$ is the maximum potential transpiration; $\lambda$ is a fitted exponent (a calibrated value); and the subscript $i$ refers to the growth stage (the OPDM uses five growth stages, so, $\mathrm{n}=5$ ).

- The salinity output, plant development stage, soil fertility, soil water content and salinity content impact on crop yield is modeled through the approximate equation:

$$
Y_{\text {rel }}=100-B_{s}\left(E C_{e}-A_{s}\right)
$$

Where: $Y_{r e l}$ is the relative yield (\%); $A_{s}$ is the threshold salinity $(\mathrm{dS} / \mathrm{m}) ; B_{s}$ is the rate at which relative crop yield declines with increasing salinity, beyond $A_{s}(\%$ per $\mathrm{dS} / \mathrm{m})$; and $E C_{e}$ is the salinity of the soil water extract $(\mathrm{d} S / \mathrm{m})$.

The Penman-Monteith equation's distinct types apply to the combined technique. The combined technique generates some of the most complicated and comparatively precise $E T_{o}$ formulas. The Penman-Monteith equation is: 


$$
E T_{o}=\frac{0.408 \Delta\left(R_{n}-G\right)+\frac{890 \gamma U_{2}\left(e_{a}-e d\right)}{T+273}}{\Delta+\gamma\left(1+0.339 U_{2}\right)}
$$

\subsection{Current economic value of water}

In this article, the economic value means economically the quantity of crop productivity (the net income of some grown region; in our case Sharkia Governorate) over the quantity of agricultural water resources for each plant.

An important indicator, which is the average value per unit of water used, can be considered the economic value. Productivity, however, is a performance measure defined as the yield and entry proportion. For the entire scheme or a single component, production can be evaluated. Two production indices could account for all or one of the outputs of the production system [15]:

- Total production: the proportion of the complete production over the complete input;

- Partial production: the proportion of the complete production over of one or more items within system.

Water's economic value is a partial production variable that estimates how water is converted into economic value by the processes. It can be acknowledged as its overall concept:

\section{Economic value $=$ Output Derived from Water Use (Net income)/Water Input}

It is possible to organize and present economic value in several distinct ways. Typically, however, they can include two separate parts: total income and total expenses. The measures needed to evaluate these segments in detail are as follows:

\section{- Total Income (TI)}

Estimating complete output is the first stage in estimating total income. Total output includes the primary crop yields, by item, and the related rates.

$$
T I_{i}=P_{i} \times D_{i}
$$

Where: $P_{i}=\operatorname{crop}$ price $(i)(\mathrm{EGP} / \mathrm{Ton}) ; D_{i}=\operatorname{crop}$ production $(i)$ (Ton).

- Total cost (TC)

Total cost includes preparing of soil, crops, fertilizers, irrigation, agricultural facilities, pest control, harvesting, storage of crops, and costs of government expenditures. The variable cost calculated by the related rates multiplying the amounts of each entry.

$$
T C_{i}=C_{i} \times Q_{i}
$$

Where: $C_{i}=\operatorname{crop} \operatorname{cost}(i)(\mathrm{EGP} / \mathrm{Ton}) ; Q_{i}=\operatorname{crop}$ production $(i)$ (Ton).

- Net Income (NI)

Net income calculated as the difference between total income; total complete cost.

$$
N I_{i}=T I_{i}-T C_{i}
$$

Where: $T I_{i}=$ Total crop income $(i)(\mathrm{EGP}) ; T C_{i}=$ Total cost of crop $(i)(\mathrm{EGP})$. 
- Water input (WI)

The water input can be considered as quantity per cubic meter. Input of water is the water requirements for crops multiplying by the area planted.

$$
W I_{i}=W_{i} \times A_{i}
$$

Where: $W_{i}=$ crop water duty $(i)\left(\mathrm{m}^{3} /\right.$ Feddan $) ; A i=$ crop planted are $(i)($ Feddan $)$.

- Economic value of water (EV)

The present research calculates the economic value of irrigation water by implementing value-added technique:

$$
E V_{i}=N I_{i} / W I_{i}
$$

Where: $E V_{i}=$ crop net revenue $(i)(\mathrm{EGP}) ; W I_{i}=$ crop water requirements $(i)\left(\mathrm{m}^{3}\right)$.

\section{The case study}

\subsection{General information}

The irrigation area at the Governorate of Sharkia is chosen as the case study. The boundaries of Egypt governorates are presented in Figure (1-a) while the case study, Sharkia governorate, is shown in Figure (1-b).

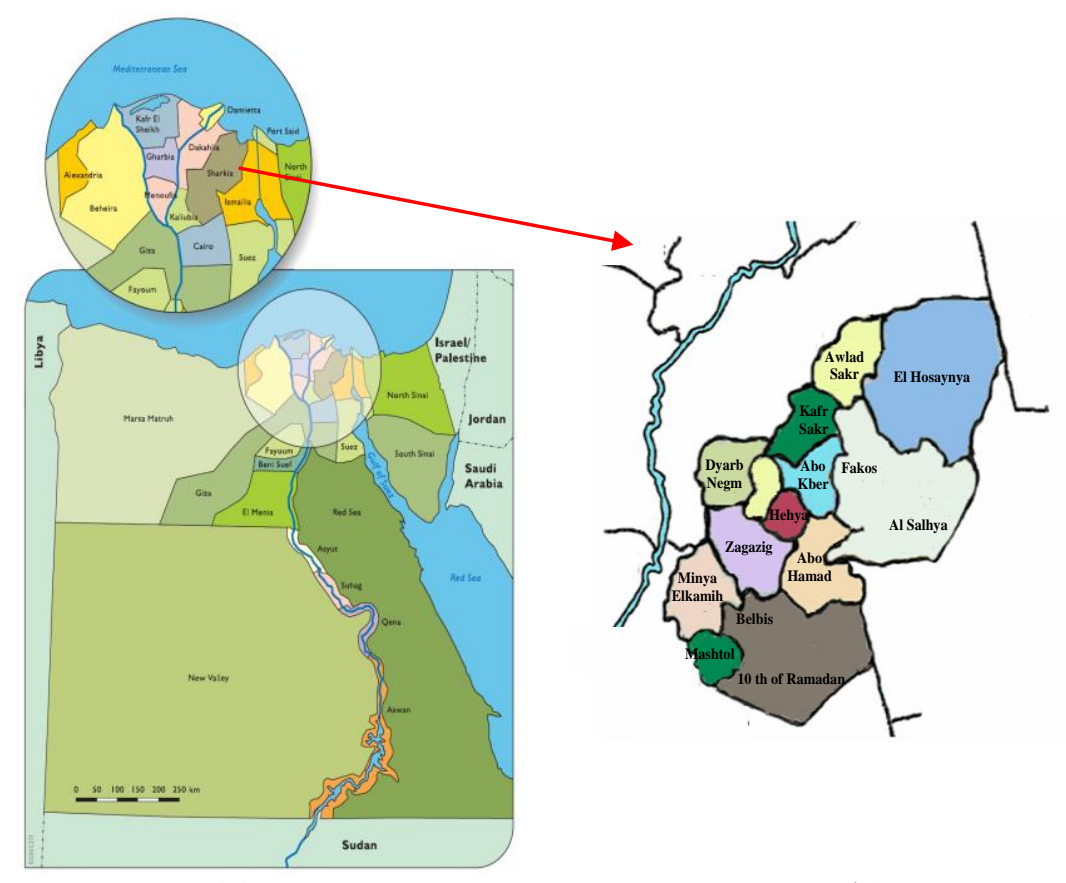

(a)

(b)

Figure 1: The boundaries (a) Egypt governorates [4] (b) Sharkia governorate

The project area is located at latitude $32.5^{\circ} \mathrm{N}$ and $30^{\circ}$ longitudinal at an elevation of $10 \mathrm{~m}$ above the mean sea level. The speed of wind used to calculate the evapo - transpiration is the 
speed at $2 \mathrm{~m}$ above ground. A network of irrigation channels feeds the region. In addition, the surplus water is discharged through open drain network. Some water, together with surface water, is drawn from an aquifer and used for irrigation.

\subsection{Canals and drains alignment}

Sharkia Governorate's waterways network is composed of open diches, shown in Figure 2 as presented in OPDM model. The project area is about 972642 Feddan, it is divided into three departments (East Sharkia, West Sharkia and Salhya), as presented in Table 1.

Table 1: Sharkia Governorate departments, canals and drains

\begin{tabular}{|c|c|c|c|c|}
\hline Department & Divisions & $\begin{array}{c}\text { Area } \\
(\text { Feddan })\end{array}$ & $\begin{array}{c}\text { Canals length } \\
(\mathrm{km})\end{array}$ & $\begin{array}{c}\text { Drains length } \\
(\mathrm{km})\end{array}$ \\
\hline East Sharkia & 5 & 211233 & 789 & 361 \\
\hline West Sharkia & 5 & 303851 & 1144 & 798 \\
\hline Salhya & 7 & 457558 & 700 & 212 \\
\hline Total & 17 & 972642 & 2633 & 1371 \\
\hline
\end{tabular}

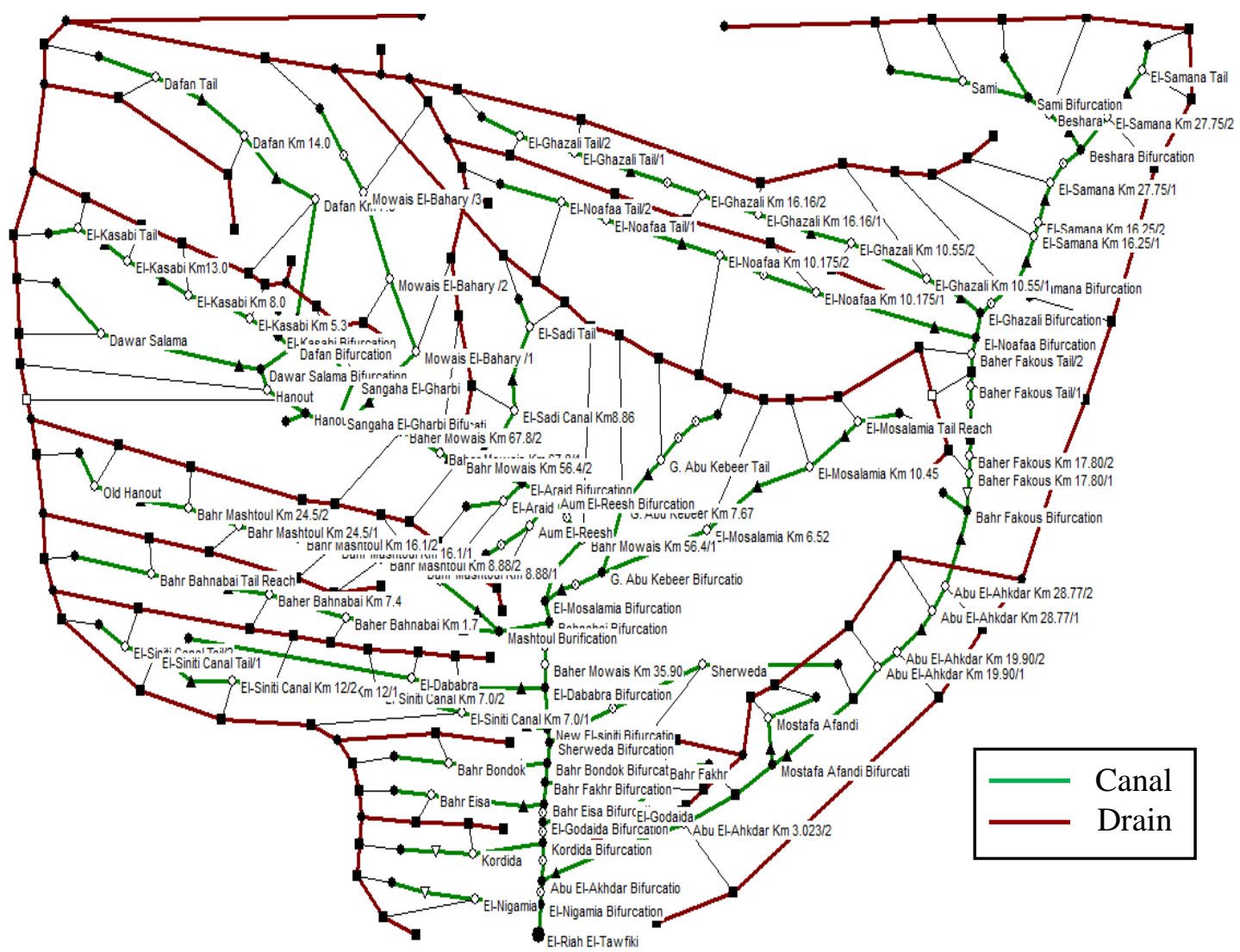

Figure 2: A schematic view of canals and drains in Sharkia governorate

The cropping pattern is simulated including the following crops (wheat, clover, cotton, rice, maize, beans, gardens, vegetables and medical plants). 
The cropping pattern indicates the yearly sequence and spatial arrangements of crops. Furthermore, the cropping pattern reflects the comparative status of specific crop importance to the total cultivated areas.

\subsection{Current water resources}

The present water resources in the governorate of Sharkia are displayed including the parameters of surface and groundwater as shown in Table 2. The main source of surface water is El-Riah El-Tawfiki canal. Furthermore, the groundwater sources are governmental and non- governmental wells.

Table 2: Water resources quantity and quality

\begin{tabular}{|l|c|}
\hline \multicolumn{1}{|c|}{ Variables } & Quantity \\
\hline Surface water quantity $\left(\mathrm{m}^{3} / \mathrm{sec}\right)$ & 138.9 \\
\hline Surface water salinity $(\mathrm{ds} / \mathrm{m})$ & 0.85 \\
\hline Groundwater quantity $\left(\mathrm{Mm}^{3} /\right.$ year $)$ & 500 \\
\hline Groundwater salinity $(\mathrm{ds} / \mathrm{m})$ & 0.85 \\
\hline
\end{tabular}

\section{Analysis of the results}

Running the simulation process, the following, Figure 3, shows evapotranspiration calculated from simulation model per crop type. It is obvious that maize and rice are the largest irrigation water consumption as they reach 465 and $410 \mathrm{Mm}^{3}$ with percentages $21.7 \%$ and $19.1 \%$ of the total water consumption respectively during the year of research. Moreover, the percentages of water consumption of the other crops reach $16.3 \%, 13.2 \%, 10.3 \%, 9.7 \%$ and $9.7 \%$ for clover, cotton, wheat, vegetables and others respectively.

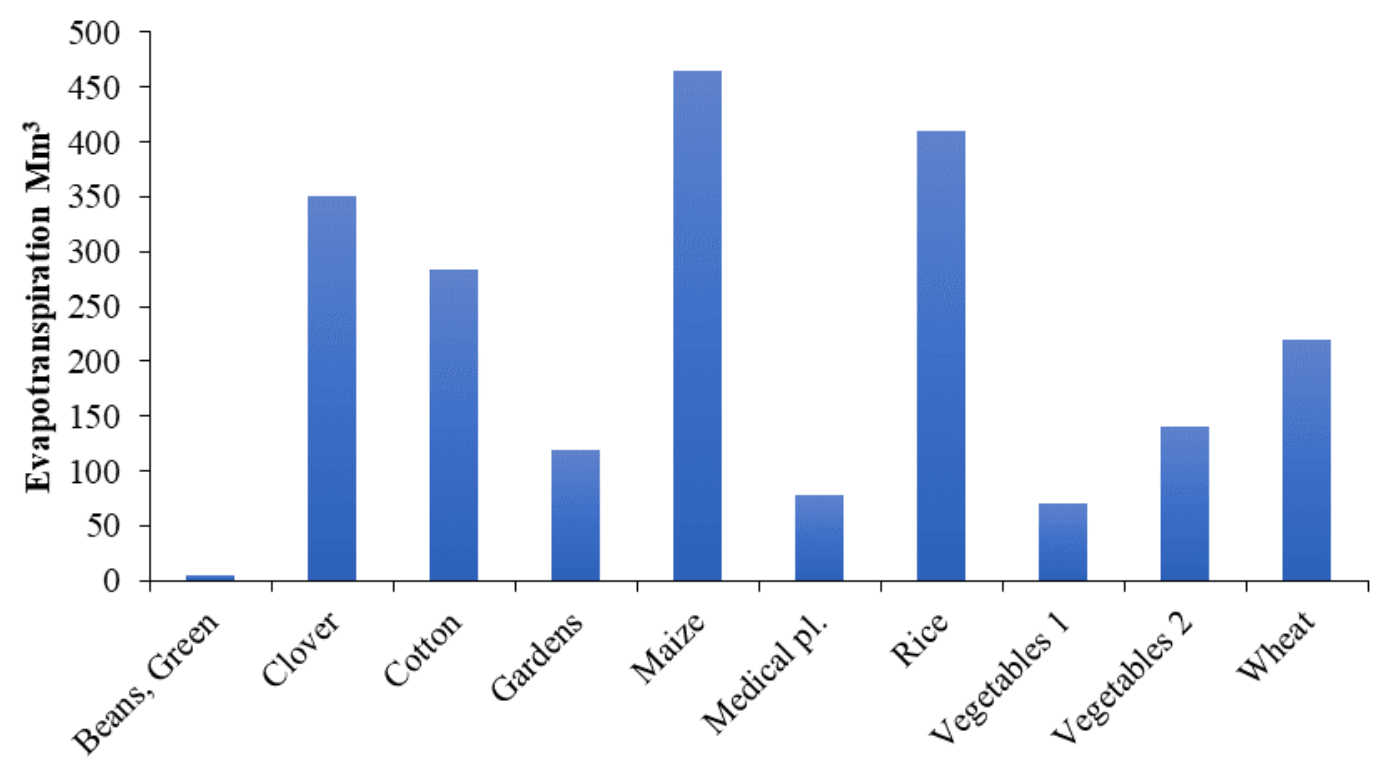

Figure 3: The evapotranspiration $\mathrm{Mm}^{3}$ by crop type 
Table 3 shows the total gross income by crop type. The total gross income of Sharkia Governorate is 942.955 Million EGP. Moreover, wheat and cotton are the greatest crops in gross income by about $31.4 \%$ and $29.3 \%$ of the total income respectively. Furthermore, the gross incomes for maize and rice are $1.7 \%$ and $17.4 \%$ of the total income respectively. Thus, the highest water consumption crops, maize and rice, are not the greatest income crops.

Table 3: The gross income by crop type

\begin{tabular}{|c|c|}
\hline Crops & $\begin{array}{c}\text { Gross Income } \\
\text { (million EGP) }\end{array}$ \\
\hline Beans, Green & 0.62 \\
\hline Clover & 92.99 \\
\hline Cotton & 276.12 \\
\hline Gardens & 26.51 \\
\hline Maize & 16.16 \\
\hline Medical pl. & 7.72 \\
\hline Rice & 164.82 \\
\hline Vegetables 1 & 8.72 \\
\hline Vegetables 2 & 62.27 \\
\hline Wheat & 295.74 \\
\hline
\end{tabular}

\section{The economic value of water}

In this paper the net income expressed as the total crop price subtracts the cost of production. The economic value of irrigation water at Sharkia governorate for each crop could be represented in Table 4. Furthermore, the previous analysis and the current table indicate that wheat and cotton are the highest crops in the economic value of irrigation water as it reaches 1.23 EGP $/ \mathrm{m}^{3}$ for wheat and $0.98 \mathrm{EGP} / \mathrm{m}^{3}$ for cotton.

Table 4: Economic value of irrigation water

\begin{tabular}{|c|c|}
\hline Crops & $\begin{array}{c}\text { Economic value } \\
\left(\mathrm{EGP} / \mathrm{m}^{3}\right)\end{array}$ \\
\hline Beans, Green & 0.21 \\
\hline Clover & 0.27 \\
\hline Cotton & 0.98 \\
\hline Gardens & 0.19 \\
\hline Maize & 0.03 \\
\hline Medical pl. & 0.10 \\
\hline Rice & 0.41 \\
\hline Vegetables 1 & 0.13 \\
\hline Vegetables 2 & 0.42 \\
\hline Wheat & 1.23 \\
\hline
\end{tabular}


Figure 4 describes the economic value of crop irrigation water arranged from highest to lowest, wheat is the highest with $1.23 \mathrm{EGP} / \mathrm{m}^{3}$ of irrigation water while maize is the lowest with $0.03 \mathrm{EGP} / \mathrm{m}^{3}$ although it is the highest water consumption crop.

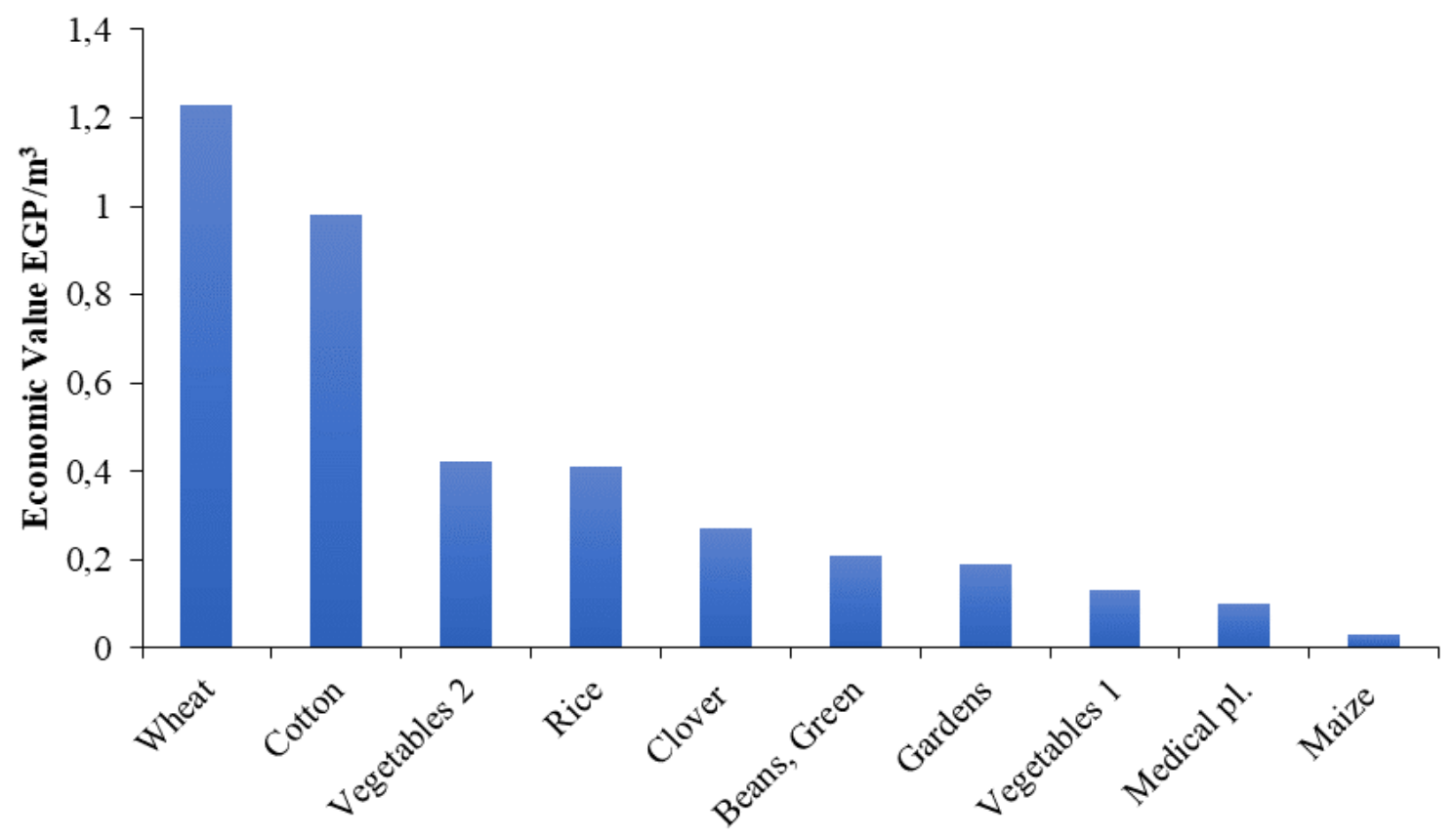

Figure 4: The economic value $\mathrm{EGP} / \mathrm{m}^{3}$ by crop type

From the figure it could also observed that the economic value of irrigation water for maize is $0.03 \mathrm{EGP} / \mathrm{m}^{3}$, and for rice is $0.41 \mathrm{EGP} / \mathrm{m}^{3}$.

\section{Conclusion}

The present paper's primary goal is to scrutinize the financial outcomes of irrigation water. Moreover, the political requirements for distribution, managing and dominance of the water resources have been taken into consideration. Water's economic value helps policymakers making informed decisions about water supply. Operational, Planning and Distribution Model (OPDM) has been used to monitor the water distribution and crop yield. Moreover, simulations of surface and groundwater under the current quantities and qualities are conducted, also their reflective impact on gross income are investigated. Furthermore, the study assesses the current cropping pattern for the government. It is obvious that maize and rice are the largest irrigation water consumption as they reach 465 and $410 \mathrm{Mm}^{3}$ with percentages $21.7 \%$ and $19.1 \%$ of the total water consumption during the year of research. Moreover, wheat and cotton are the greatest crops in gross income by about $31.4 \%$ and $29.3 \%$ of the total income. It is concluded that maximum economic values of irrigation water are $1.23 \mathrm{EGP} / \mathrm{m}^{3}$ and $0.98 \mathrm{EGP} / \mathrm{m}^{3}$ for wheat and cotton respectively. Furthermore, the gross 
incomes for maize and rice are $1.7 \%$ and $17.4 \%$ of the total income respectively. Thus, the highest water consumption crops, maize and rice, are not the greatest income crops. Finally, these results may highlight the future production of some strategic crops.

\section{Acknowledgements}

The authors expressed their sincere gratitude for the available facilities of the Department of Water and Water Structures Engineering, Faculty of Engineering, Zagazig University.

\section{References}

[1] Ayman, A., Graham E. \& Mohsen A. (2013). Water use at Luxor, Egypt: consumption analysis and future demand forecasting. Environ Earth Sci, DOI 10.1007/s12665-013-3021-8.

[2] Zhang J., Bai M., Zhou S. \& Zhao M. (2018). Agricultural Water Use Sustainability Assessment in the Tarim River Basin under Climatic Risks. Water, No. 10, 170; doi:10.3390/w10020170.

[3] MWRI (2013). Adaptation to Climate Change in the Nile Delta through Integrated Coastal Zone Management. Ministry of Water Resources and Irrigation.

[4] MWRI (2005). National Water Resources Plan for Egypt 2017. Available at http://extwprlegs1.fao.org/docs/pdf/egy147082.pdf, accessed [10-11-2018].

[5] El-Atfy H. \& Kotb T. (2004). Water Valuing: a Tool for Demand Management in Egypt. Workshop on Water Demand Management in Egypt, Framework of the $38^{\text {th }}$ Meeting of the Advisory Panel Project on Water Management, Nigmegen, The Netherlands.

[6] Ward A. \& Michelsen A. (2002). The economic value of water in agriculture: concepts and policy applications. Water Policy; 4:423-46.

[7] NWRP (2003). National Water Resources Plan (2003) Facing the Challenge. Outline of a Draft Strategy, NWRP Discussion Paper No. 3, Egypt.

[8] Abdel-Aziz Y. (2002). Cost Recovery in Water Systems, Workshop on Financing and Cost Recovery of Agriculture Water Systems. Advisory Panel Project on Water Management, Haarlem, the Netherlands.

[9] Shalaby A., Sadek T., Kotb T. \& Mostafa M. (2003). Inter-ministerial Water Policy Integration. Water Policy Advisory Unit, Report No. 71, Ministry of Water Resources and Irrigation, Egypt.

[10] Young R. (1996). Measuring economic benefits for water investments and policies. 1119. Washington: World Bank Technical Paper 338. https://doi.org/10.1596/0-8213-3745-9.

[11] Nimah M. (2004). Maximizing irrigation scheme water productivity based on optimum cropping pattern. Nat Water Res Center J.

[12] Mohan Z., Ray S. S. \& Panigrahy S. (2005). Analysis of runoff pattern for all major basins of India derived using remote sensing data. Current science, Vol. 88, No. 8, 25.

[13] Anandan P. S. \& Venkatesh G. (2005). Surface water estimation using GIS. Proceedings of the National seminar innovative techniques for sustainable development of water resources, March $24-25$.

[14] USU (1996). Operation and planning distribution model (OPDM). Soft User's Guide, Ver. 2.02, Department of Biology and Irrigation Engineering, Utah State University (USU), Logan, UT. 
[15] Hosni H., El-gafy I. K., Ibrahim A. H. \& Abowarda A. S. (2014). Maximizing the economic value of irrigation water and achieving self sufficiency of main crops. Ain Shams Engineering Journal, No. 5, 1005-1017. 